\title{
Subaltern Praxis: \\ A Vygotskian and Freirean Framework in NGO Education
}

\author{
Shireen Keyl \\ Utah State University \\ U. S. A.
}

ABSTRACT: This article examines the functionality and ideological underpinnings of an NGO system in Beirut, Lebanon. This grassroots NGO, in partnership with the Migrant Community Center and migrant domestic workers from African and Southeast Asian countries, creates an educational space that is both transformative and liberatory. This activist space is informed by an anti-racist and feminist ideology. Based on the narratives of this system's stakeholders, I forward a subaltern praxis, a transformative model for the development sector informed by Vygotsky's constructivist frameworks and Freirean ideology.

KEYWORDS: NGO education, migrant workers, Freirean pedagogy, Vygotsky, subaltern.

The Development Sector and Education

Research Context

The NGO System

Discussion: Subaltern Practice in the NGO System

Conclusion

References

In 2010, I had the opportunity to volunteer at a non-governmental organization in Iran that served women from disenfranchised backgrounds. Western-educated researchers at this NGO attempted to utilize "empowerment" strategies for these young women. The use of self-esteem workshops and their ideology worked well in the space of the center; but, those ideas lost all meaning once the women stepped outside of the center into Tehran's streets. This ideological disconnect did not serve them nor empower them. As a result of this experience, I desired to study how community-led, grassroots NGOs in Middle East countries circumvent Western development strategies by privileging local and community knowledges: How do they do this? What was the result?

This qualitative study seeks to examine how stakeholders, such as teachers, coordinators, and migrant students conceptualize education in a nongovernmental organization (NGO) setting. I conducted fieldwork at a grassroots 
NGO in Beirut, Lebanon to learn about the ideological underpinnings of these particular NGOs and volunteer groups. In what follows, I offer a critique of the theory and practice of the international development sector. Next, I present data from participant observation, focus groups, and the narratives of coordinators, teachers, and migrant students at the NGO system in which I performed this study. Finally, I provide a discussion and analysis of how this NGO system exemplifies what I assert is subaltern praxis in NGO education.

\section{The Development Sector and Education: A Theoretical and Practical Disconnect}

International development work has its roots in Europe's colonization of the Global South in the late nineteenth/early twentieth century and paved the way for the technical and material assistance known today as "development" (Rist, 2019, p. 47). The academic discipline of development studies (DS) has its origins in the institutions of the United Kingdom, which parallels the colonial legacy of that region (Kothari, 2019). The formation of this discipline and the practice of development can also be traced to the devastation of World War Il's effects on the world economies. United States foreign policy in the post-World War II era called for preemptive measures to counter the threat of communism in Europe. One such measure was President Harry S. Truman's introduction of the Point Four Program, which included an ambitious plan to alleviate poverty and disease and bring prosperity and democracy to "under-developed" countries (McMichael \& Weber, 2016; Rist, 2019). This program served as the impetus for the international development sector we know today.

The metanarratives that drive the development sector and which are central to its scope and meaning as an action-oriented field of study emerge from economics and policy studies. Because these fields of study are viewed as positivist, more focused on measurable and immediate outcomes and more driven by applied research, the field of development studies has been and presently still is rife with criticism. Varying aspects of DS generate contentions, often being referred to as an "uneasy discipline" (Schuurman, 2009, p. 831) while other scholars consider "rethinking" development as a discourse and study (McMichael \& Weber, 2016, p. 299). The term "development" in and of itself is problematic, as it refers to "both the ideal of improvement in people's well-being and to a far more dystopian reality on the ground" (Bhavnani et al., 2009, p. 1).

By virtue of attempting to amend the problems of poverty, the development industry and major actors of this entity superimpose Western-influenced, prescriptive ideas to produce change in the Global South. The very notions of "development" and "poverty" are social constructs, from a poststructuralist perspective, not existing outside of its objective realm (Sumner \& Tribe, 2008, p. 14). For this reason and others, critical development scholars assert that development as a theory and practice is in great need of a theoretical paradigm shift. For instance, in speaking about development initiatives that specifically involve education projects, Appadurai (2000, p. 17) calls for "new forms of pedagogy" in the vein of Paulo Freire within a "grassroots globalization" movement, while a handful of post-development scholars acknowledged the breadth of 
knowledge that Freire and other critical pedagogues contributes to the field of DS (Desai \& Potter, 2013; Escobar, 2000, 2011; Tucker, 1999).

This paper intends to fill the gap that exists in the literature regarding NGO education within the development sector in terms of offering a subaltern praxis. This transformative and liberatory theory and practice take into consideration the ontological and epistemological experiences of oppressed groups (in this case, migrant domestic workers) within an NGO system that functions in a horizontal, reciprocal style, driven by local community politics, organized in a bottom-up, grassroots style. By calling on Vygotsky's work on scaffolding and Freire's critical pedagogical thought, I take heed to Appadurai's (2000) call for new forms of pedagogy.

\section{Research Context: Three Grassroots NGOs in Beirut, Lebanon}

In 2012, I spent three months as a researcher-practitioner in Beirut, Lebanon conducting fieldwork at the Migrant Center (MC), a community center for migrant workers. Two other organizations worked in tandem to support the MC: Tamkin, a feminist grassroots NGO, financially and administratively supports the MC. The Migrant Worker's Educational Group (MWEG) is a group whose purpose is to provide educational opportunities to migrant workers by recruiting volunteer teachers to teach language classes and computer classes at the MC. During the time that I was there, I was a participant observer for MWEG, teaching English classes and helping as an assistant to the $\mathrm{MC}$ coordinator. The physical site of my fieldwork took place at the MC, which was in the Naba'a neighborhood of Beirut, Lebanon. The MC was established in 2011 as a social, cultural, and activist space for the diverse East Asian and African communities in Lebanon.

\section{Research Participants}

For this paper, research participants included MWEG volunteer teachers: two teachers were Lebanese, one was Italian, and one was Lebanese-French. Other research participants included the Lebanese administrator of Tamkin, the feminist organization, and the Nepali coordinator of the MC. For my in-depth interviews, I used the purposive sampling strategy of snowball sampling to achieve "representativeness," which is the technique that "involves using [participants] to identify additional cases who may be included in the study" (Teddlie \& Tashakkori, 2009 , p. 175). An example of this is when participants would suggest a migrant domestic worker who they believed would be interested in talking to me.

\section{Data Collection Tools and Data Analysis}

This IRB-approved and monitored qualitative research study employed indepth interviews, focus groups, and participant observation. In analyzing my data, I utilized grounded theory, which consists of "...systematic, yet flexible guidelines for collecting and analyzing qualitative data to construct theories 'grounded' in the data themselves" (Charmaz, 2006, p. 2-3). A grounded theory approach values a posteriori knowledge, or knowledge dependent on experience; grounded theorists advocate for "developing theories from research grounded in data" (Charmaz, 2006 , p. 4). As one who advocates for the utilization of grounded theory, I adopt a 
posteriori justification when entering the research field and conducting fieldwork. Grounded theory does not aim to make generalizable claims "abstracted from empirical realities;" rather, the strength of grounded theory situates "grounded theories in their social, historical, local and interactional contexts" which strengthens theorizing claims that emerge and allows for "making nuanced comparisons between studies" (Charmaz, 2006, p. 180). As a result of recognizing the disconnect between superimposing Western theoretical constructs in NGO educational settings in the Middle East context, I have chosen to utilize grounded theory, which serves this study based on my previous NGO experience in other Middle East countries. This study aims to contribute an emergent theory and practice of subaltern groups to explain how knowledge production and power are intertwined and create liberatory and resistance frameworks that function in educational and community spaces.

\section{In-depth Interviews}

The in-depth interviews took place throughout the three months I conducted fieldwork. As mentioned above, research participants were the volunteer teachers, NGO coordinators, and migrant students. Teachers and coordinators were interviewed at a place of their choosing. All interviews were audio-recorded with participants' approval. All interviews were transcribed.

As a starting point, I used a list of questions to begin the interview; however, the in-depth interview does not work off of a script of questions. On the contrary, the interview process is an organic process, one in which the interview becomes a dialogue, a space where the participant feels safe to share his or her lived experiences and her reflections on those experiences. As Seidman (2006) states,

The in-depth interview is not to get answers to questions, nor to test hypotheses, and not to "evaluate" as the term is normally used. At the root of in-depth interviewing is an interest in understanding the lived experience of other people and the meaning they make of that experience. (p. 9)

Sample questions for migrant domestic workers included: Do they find the educational opportunities useful, and in what ways? How do their lived experiences inform the ways they interpret the world? How do they use the advice given to them by friends and family? How do they use their formal and/or informal educational experiences? What does the MC represent for them, and how does it meet their needs?

\section{Focus Groups and Participant Observation}

This research project took place in the space of the MC, at which I spent time every day, and in my classroom space on Sundays where I taught English. It is within these spaces that I utilized the research methods of participant observation and the focus group. Ethnography, according to Heath and Street (2008), "forces us to think consciously about ways to enter into the life of the individual, group, or institutional life of the "other"' (p. 31). By applying an ethnographic lens as a researcher in the classroom, my aim was to (with the permission of my participants) become aware of the attitudes, opinions, and ideas 
of the students in my class. Participant observation helped me understand how the students drew conclusions about knowledge and what informed their knowledge base.

\section{The NGO System: Tamkin, the Migrant Center, and the Migrant Workers Educational Group}

In the following sections, I present my observations of the teaching space and the narratives of the teachers. I also present interview excerpts from migrant students and coordinators. I organize this data to reflect the common themes that arose in the data analysis that speak to issues of an empowering subaltern practice in NGO systems.

\section{Tamkin: A Feminist Collective}

"Tamkin" is an internationally recognized grassroots feminist organization located in Beirut and is the NGO that oversees the operations of the Migrant Center. Tamkin employs a feminist framework in its support of various initiatives so as to instill within women and society at large a sense of empowerment through anti-racism activism and support for social change. By way of a feminist agenda, the mission of this organization seeks to counteract Lebanon's xenophobic, racist, and patriarchal systems. In January 2010, Tamkin was born out of a frustration of the existing NGO platforms that occupy Beirut's development infrastructure. Several factors set this organization apart from the traditional NGOs in Beirut. Tamkin's organizational structure as a "collective" in which all members have an equal voice and have free choice in how they will contribute makes this group different from others. Tamkin provides the educational and activist space for members to convene, discuss, and put into action an initiative of their own creation. I asked Fakira, the general coordinator of Tamkin, how this organization came to be in existence. She explained,

We are registered as an NGO but we do not refer to ourselves as an NGO because we don't have a typical NGO system. The reason that [our organization] was started was because there are many women's organizations around us in Lebanon. But none of them were able to fill the gap that we, as young women, wanted. We want to work on things, and feel ownership of things, and do changes in a certain way. None of those NGOs and organizations had this opportunity for us. This is why this space is safe and open for feminists and others and accepting of all people regardless of anything.

In the above excerpt, Fakira mentions an absence of a core feminist framework in other NGOs in Beirut. Most other social service organizations in Beirut are usually aligned with a particular religious or political entity; it is the desire of Fakira and the other co-founders of Tamkin to provide an inclusive space that is informed by a feminist, decolonial, and critical ideology.

\section{The Migrant Center: Scaffolded by Tamkin}

Fakira works in tandem with the Migrant Center's coordinator to see that its objectives are met as a center that values the local knowledges of migrant workers 
and community leaders. The on-site coordinator of the Migrant Center is Suba, a 25-year-old Nepali woman. She was hired as the on-site coordinator because, as a former migrant domestic worker, she is intimately knowledgeable about the migrant worker experience; this uniquely positioned her to meet the needs of the MC. The MC came into existence due to Fakira and other activists seeking out the opinions and input of the migrant workers themselves in terms of their wants and needs from NGOs. Here, she discusses the MC:

Fakira: The Center is a space that is open to community leaders and migrant workers. This past year, the most urgent issue was that they needed a space....before all the other issues, such as shelter, they wanted a space to be able to use as a community space to do events, meetings, follow up on [legal] cases, have computers that have Internet, have phone access.

SK: Is this space [the Migrant Center] specifically for migrant workers?

Fakira: Specifically for migrant workers, yes. It's not an office space for us [Lebanese] to go use. It's supposed to be totally independent in its functioning. We coordinate every single day, me and Suba. We have common meetings, Suba, as part of Tamkin's other initiatives, of course many common things. But the MC space, it is supposed to have a totally different dynamic...it's not supposed to be a shared space for us, it's the migrant workers' space.

Fakira sought out the migrant workers' opinions to learn exactly what their greatest need was, and the migrant workers responded that they needed their own space to hold meetings, provide services, and hold classes. In my interview with Suba, she reiterates how Fakira desired migrants' input:

We used to rent space for meetings and it was very expensive. So Fakira was asking us last year what we [the migrant workers] wanted, what were the migrants' needs. We community leaders meet the second week of the month. And now we meet here.

Suba also states that finding random places to meet was difficult due to the racism they encountered at coffee shops - no business wanted migrant workers congregating in their spaces. Also worthy of note is that Suba and Fakira meet daily so that Fakira can offer administrative support. Suba's role as the MC coordinator is a position of leadership, and Fakira recognized it as such. By offering a scaffold of support, Suba feels supported as a leader and decision maker.

\section{The Migrant Worker's Educational Group: Volunteer Teachers in an NGO Classroom}

The Migrant Worker's Educational Group is a grassroots organization whose purpose is to provide educational opportunities to migrant workers by recruiting volunteer teachers to teach language classes and computer classes. The languages offered during my time with MWEG were English and French.

MWEG is not an established NGO. Because MWEG relies on volunteers for teaching and the generosity of NGOs or other groups to offer the physical space 
to hold classes, they do not have the expense of a monthly rent payment, which keeps their overhead costs fairly low. According to their website, the MWEG defines itself as "a grassroots volunteer organization that leads initiatives for better treatment and social advancement of the migrant worker community in Lebanon" with the aim "to improve the situation of migrant workers in Lebanon through grassroots initiatives" by way of offering educational opportunities such as English and French classes as well as computer classes (Migrant Workers Task Force, n.d.).

Usually on Sundays, prior to teaching, the teachers hold a meeting to touch base about housekeeping details, such as making sure everyone has copies of the readings, answer questions for the students, and for teachers to discuss their own teaching experiences and observations. During one meeting, they discussed the structural challenges of teaching migrant students, such as their inconsistencies in attendance and repeated absences. A teacher commented it is difficult to push the students forward curriculum-wise when they do not attend classes. Someone else replied that these migrant domestic workers are often taken to their employers' summer homes in the mountains for weekend getaways and they have no choice in the matter. Another teacher said that maybe they do not attend regularly because they feel ashamed that they have not done the homework or they feel unprepared.

One of the volunteer teachers went on to say that he believed the students came to the MC not only to learn, but also because they felt safe here. Maha, a volunteer teacher and coordinator, stated, "This is the point of social justice. While it's important they learn, it's not always the whole point for them. It's about providing a safe and empowering space."

In my interviews with other volunteer teachers, most understood the daily struggle migrant domestic workers face in a xenophobic society, and most of the Lebanese volunteers belong to upper-middle-class families who employ migrant domestic workers. Omid, a Lebanese 21-year-old medical student recalls specific incidents from his childhood that prompted his present involvement with migrant activism.

Omid: When I was growing up, I was best friends with the domestic worker who used to work in my home. My parents were very much against that. They were like, there is classism that we cannot get over. We are from a different class than they are, they said. We should accept them but we cannot be friends. This person cannot be your best friend, you need to find friends elsewhere.

SK: So, when you were growing up, you saw these injustices... You are quite cognizant of these injustices...

Omid: I saw them, but in the end, I got shunned by all of my surroundings, my family, my friends, my principal at school. Even my therapist! Even my therapist told me, "Know this cannot happen. You cannot be friends with your domestic worker." In my mind that never clicked, that made no sense. 
This experience affected Omid so much that he decided to participate in different groups and NGOs in Beirut that assist migrant workers. He talks about how his involvement made him come to terms with his own discrimination:

When I came to [local NGO group], I learned more about discrimination. I also discovered that maybe myself had some discrimination in my mind. I used to discriminate without knowing. And that's how I got to realize that. Later on I learned from another local NGO group; that was a starting point. I got to know other human rights issues. I discovered other injustices in Lebanon.

Other volunteer teachers talked about building trust and reciprocity with their students. Twenty-six-year-old Sofia from Italy, who lived in Syria prior to the 2011 war, speaks Arabic and is getting a master's degree in Islamic Studies from the American University of Beirut. Here, she comments on building relationships with students:

First of all, when you want to teach someone, you need the other person to trust you, to feel comfortable with you. So I allow joking in class, not bad jokes, but we laugh, we have to be focused, but sometimes we have five minute break, and we just talk about our lives, what we do. Since I have spent time in Ethiopia, I told my Ethiopian student where I was in Ethiopia; I told her the two or three words I know in Amharic, and she was impressed, and they told me about their lives, what they do, how they feel in Lebanon, and these kinds of things. The thing I like the best is that they are really happy when they see me. When I arrive, you can actually feel they are happy to see me, it's a nice feeling.

Here, Sofia describes how she wants to protect her students from negativity and authoritarian teaching practices:

Last time in class there was a new Lebanese guy, Salim, who came to the Center to observe and help us with teaching, and he did a really bad thing. He asked Mahmoud [a migrant worker from Egypt] to pronounce, "p", and Mahmoud, he did the best he could, and to me, he did pronounce it " $p$ ". But Salim, he said, "No, you are pronouncing it as if it is 'b'. Say 'p'! 'p'!" See, in Arabic, there is no " $p$ ", and Mahmoud did the best he could. And then Salim said, "The reason why you do that is because you are Egyptian; you cannot pronounce the 'p' correctly." And Mahmoud was looking at me, like, "Is it true? Do I pronounce wrong?" And I told him, "It's not true, you are pronouncing it well, you are gonna improve, and you are doing a very good job, it's fine, it's ok." I was upset, because you should not say these kinds of things, "Your pronunciation is bad because you are Egyptian." I stopped Salim when he was saying this.

Experiencing some kind of marginalization (not necessarily vis-à-vis migrant workers), either personally or by observation, has motivated some volunteer teachers to participate in a cause that aligns with the migrant worker cause. Ashraf is a Lebanese-French volunteer teacher and I asked him his reasons for volunteering as a French teacher. He explained, 
I really like that this teaching opportunity was suggested by Suba [the Nepali MC coordinator]. So, it was not from a Lebanese organization, to help migrants, it was more equal. And, because of this, my relations with the students are also horizontal, because it comes from Suba who used to be a migrant worker.

Ashraf commented that there are some Lebanese people who are encouraged to volunteer in some capacity by the university career services office, which can be listed on their resume. "When you are sent from your university to do something good to benefit your CV, of course you don't have the same experience as someone else who is there for more altruistic reasons."

What Sofia describes above about trust in the classroom parallels Omid's reflections as well.

It's very important for the students to be very comfortable with you as a teacher. And here, it's a different setting; I'm a younger person who is teaching people who are older. So this comes as a small challenge that you get over fast. They are saying you have this information. They are trusting you.

Another classroom practice that I observed and heard in interviews was the idea of reciprocal teaching; meaning, the students were teaching the teacher as much as the teacher was teaching the students. Here, Ashraf, the French teacher, discusses this idea:

I teach them in English, and my English is not perfect...and some of my students are Nigerian, and their English is much better than mine. Sometimes they know more English more than me. So I have to ask them, how to spell this word, or that word.... So, to them, ok, if the teacher doesn't know something, we have a kind of new equality.

Sofia mentioned reciprocity in language teaching as well.

I was teaching Mahmoud [a migrant worker from Egypt] and we started from the alphabet. I was assessing what he knew and didn't know. We were communicating in Arabic. I think that for students who can speak Arabic, they are comfortable with me because my Arabic is not as good as theirs, so they feel like they are teaching me because I always ask them questions about Arabic. For Mahmoud, I can tell he likes that he helps me and teaches me Arabic at the same time I'm teaching him English.

The iterations relayed here of Sofia, Ashraf, and Omid are reminiscent of Paulo Freire's ideas regarding reciprocity, trust building, and relationships in the classroom (Freire, 1970 \& 2005), which are notions that inform a subaltern praxis, to be discussed shortly.

\section{"Access to the Struggle:" Migrant Domestic Worker Education for Social Justice}

Also significant was the idea of using place-based curriculum that contextualized the lived experiences of the migrant workers. In my interview with 
Abe, who taught English to students at the MWEG's Hamra location in downtown Beirut, he talked about the importance of place-based learning:

I remember looking at the EFL [English as a foreign language] textbook we were using, and it said, "John did this, Mary did that." And one of the students was like, "Why is it always 'John did this' or 'Mary did that'. Why is it never, Rahel, or Makda, or Gete [Ethiopian/Amharic names]?" I was like, "You know what? You're right. Let's change the names." So we started changing the names and working with that. And I decided that, "You know what, let's just change the whole thing." So I decided to write my own book for it.

Abe discussed the instructional issue of homework assignments, that is, being limited as an instructor and as a student by not assigning homework. Abe felt it was counter-productive to assign homework to his students because most students were not able to complete it given their long work hours. He felt, by assigning homework, the teacher set up the student to fail. In order to accommodate this issue, Abe structured his class to test them at the end of the class session: "So, my idea is, to give them the class, and then give them an exam right after."

I asked Abe his ideas about education, empowerment, and activism. In his mind, why was he teaching English? What was meant to be gained for the migrant workers, seeing that they cannot earn college credit? In his opinion, is teaching an act of activism, and why?

Yes. This is a big, big, big question for me. I have contemplated this a lot. I have asked myself, "Am I just helping? Or am I doing something to change? Why am I doing this?" And then I discovered something...other than the whole point of empowerment, the whole point that you're helping someone, and you're giving someone skills that they can really use later on. With my students, I set the bar high, maybe too high. Why? Because I never wanted them to become students. I wanted them to become learners. Now, I know that, if I leave them now, and I never show up again to class, they can pick up the language by themselves. I was always teaching them tools. I'm really sure I can leave them, and they will continue learning. I have helped them to be independent learners. So, now, if they go back to their native countries, they can teach at least. It's not like I am only empowering them [through teaching], but they will go empower their children one day.

I asked Abe if he, himself, as an English teacher, ever brought up these issues of migrant abuse, racism, and sexism into his curriculum or classroom space? Does he ever explicitly say, "This is why you need to learn English, so you can have access to the struggle?" Does he ever verbalize this?

I do incorporate it into the curriculum. On one test, for the writing assessment, I had a picture of Elizabeth Eckford, the first African American student to be integrated into an all-white school in the United States. I asked them to write how they felt about this picture. The reading assessment was a paragraph about Elizabeth Eckford, and what she did in her life, and all 
the questions were on her life. Also, they had presentations. So, I gave them a piece of difficult writing, and they had to work in pairs. I gave them dictionaries, and they had to try to understand the overall idea, decipher it. Then they had to present it to the whole class. This was an in-class graded assignment. One of the topics was on racism. "What is racism? How do you recognize racism?" Vocabulary they came across in that piece of writing was "intentional segregation." If they didn't get it, I would sit down and explain these concepts to them.

In the above iteration, Abe describes teaching his students to "read the world" (Freire, 1985), deconstructing the social meaning of words utilizing a critical race theoretical framework.

\section{Discussion: Subaltern Practice in the NGO System: Tamkin, the Migrant Center, and Migrant Worker Educational Group}

In the following section, I outline the functionalities in what I assert to be a subaltern praxis (please see figure 1), as observed within the NGO system examined in this study. First, I will describe how the entirety of the NGO system creates a "niche opening" (Nicholls, 2014, p. 28). Next, I will describe, how the MC embodies Counter-Cultural Communities of Practice (CCCoP) (Duncan-Andrade \& Morrell, 2008). I will then provide a description of how Tamkin, the feminist organization, acts as a scaffold (Vygotsky, 1978). I will then discuss how MWEG facilitates the "dark knowledges" (Zipin, 2009, p. 317) of migrant workers. Lastly, I will talk about the role of Freirean thought within this NGO system (1970), which contributes to powerful counterspaces (Yosso, 2006) of empowerment.

\section{Figure 1 Subaltern Praxis}

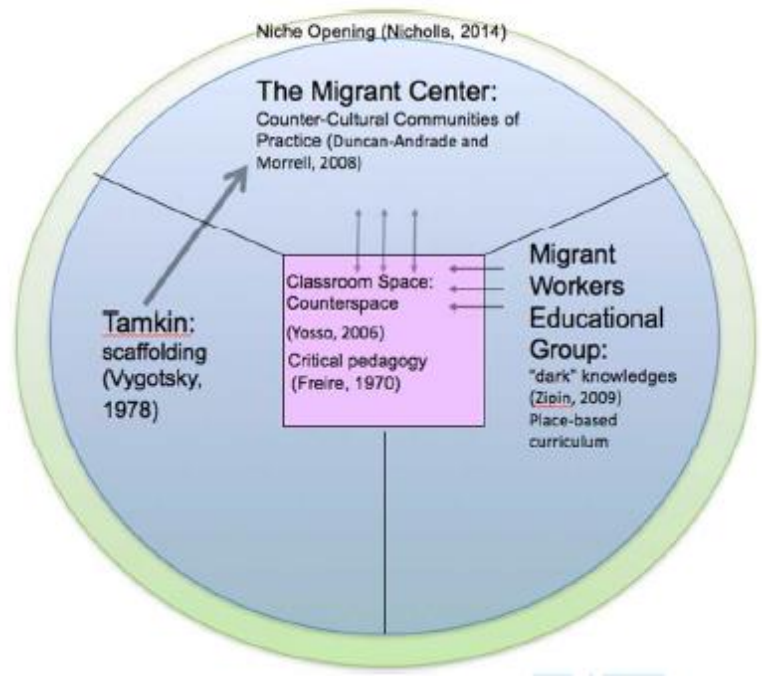

\section{Niche Opening}

The accomplishment of the activist and migrant communities working together to provide a cultural and educational space lies in a few key elements - first, the whole of the activist community (the Migrant Center, Tamkin, and MWEG) operated as a "niche opening" (Nicholls, 2014). "Niche opening" is defined as a discursive space in social, legal, or political networks in which a "moral ambivalence" exists and to which certain subaltern groups such as migrant workers or immigrants have access by way of certain "attributes to push forth rights claims in spite of general hostility and closure" (Nicholls, 2014, p. 28). If the subaltern person possesses the attributes, whether they are social networks or cultural, social, or economic capital, she or he can navigate within that niche opening as a means to an end, that being a safe space, educational opportunities, friendships and myriad forms of support and love. 


\section{The Migrant Center: Counter-Cultural Communities of Practice}

The volunteers and migrant community created powerful counter-cultural communities of practice (CCoP) (Duncan-Andrade et al., 2008), which are contextualized, empowering spaces for marginalized populations that explicitly fit the cultural, educational, and social needs of that population. The mission of the Migrant Center and its ideological positionality encapsulated a feminist vision, as demonstrated by its stakeholders, specifically Fakira, who represented the ideology of the feminist collective Tamkin, and Suba, who was acutely aware of the human rights atrocities committed against migrant workers as a former migrant domestic worker herself. In the MC's functionality, its social cohesiveness was evident in the ongoing cooperation between Suba, Fakira, migrant community leaders, and the migrant workers who used the space. Additionally, the production of services such as educational opportunities (in conjunction with other grassroots movements, initiatives, and NGO groups) and shared resources and knowledges contributed to a common vision among these cooperating organizations.

The praxical implications of the NGO synergies is explained in DuncanAndrade et al.'s (2008) idea regarding counter-cultural communities of practice, which is defined as recognizing "the existence of a dominant set of institutional norms and practices and intentionally sets itself up to counter those norms and practices" in order to develop "a critical and engaged citizenry with a democratic sensibility that critiques and acts against all forms of inequality" (p. 11). There were several indicators that reflected the counter-cultural aspect of the MC; for instance, its very existence reified a critical, transformational, and oppositional ideology held by social justice and civil rights groups that ran in direct opposition to the dominant beliefs held by Lebanese society regarding migrant workers.

While the counter-cultural communities of practice framework stems from research conducted in urban high schools in the United States, this idea was easily recognizable in (and transferable to) the MC, in that both target groups (Black and Latinx populations in the United States and African and Southeast Asian women and men in Beirut) encountered structural and systemic inequalities and racism in their everyday lived experiences in contested social spaces. This counter-cultural community of practice of the MC, as enacted by volunteer educators and students in a dialogic manner, sought to activate an oppositional and critical consciousness within migrant domestic worker-students, transforming the classroom space into an empowering, constructivist, and activist space.

The "counter-cultural" characteristic of the CCCoP model is evocative of Vygotskian thought as a lens for studying the issues of subaltern education and, in particular, the mediated learning that occurs in the relationship between culturally organized activities and cognition. In this study, most of the volunteer teachers recognized that "cognition is embedded in the social and cultural world" of the learner, which highlights the importance of "contextual factors to the cognitive process" (Moll 1990, p. ix) as evidenced by Abe's intentionality in creating curriculum that speaks to the lived experiences of migrant workers. Teachers 
recognize the criticality in contextualizing the lived experiences of their students in the classroom space, especially since their lives are fraught with almost daily direct and indirect interactions with blatant racism, xenophobia, segregation, and, in some cases, physical, mental, emotional, and sexual abuse.

\section{Tamkin as a Scaffold for NGO Management}

For the constructivist educator, Vygotskian theories, such as the sociocultural model, informs her or his classroom practices, serves as an instructional mechanism, and shapes curriculum; the teacher strives to "encourage students to see themselves and how they became themselves from the perspective of other people. In this context, we gain the benefit of self-knowledge and thus the ability to change ourselves in say, emancipatory ways..." (Kanpol, 1997, p. 68). Within the NGO system central to this study, we see many examples of Vygotsky's ideas. One idea in particular, known as "scaffolding," is defined as "the help given to a learner that is tailored to that learner's needs in achieving his or her goals of the moment" (Sawyer, 2008, p. 54).

While scaffolding is typically utilized for classroom instruction, its application is visible in the functionality of the management of the NGO system in this study. Recall that Fakira met often with Suba, the coordinator of the Migrant Center. As coordinator, Suba's duties included the management of the MC, the day-to-day duties such as being present for patrons' questions and helping with computer use and administrative duties, such as making sure bills were paid on time. Fakira gave Suba a wide girth in terms of how she chose to run the MC and Fakira was always available to assist her. They met daily so Suba had a managerial support system in Fakira's participation. Fakira acted as a scaffold instead of a manager or authority figure.

\section{MWEG and Contextualizing "Dark Funds of Knowledge"}

Most individuals who belong to marginalized, subaltern groups have experienced much stress and trauma, not only in their lives in their home countries, but also through the act of transcending borders. The migrant domestic workers relayed in interviews the trauma of transitioning into a domestic servitude role and being treated with no human decency. For children who cross borders, the trauma can be even more significant. According to Zipin (2009), such traumatic events call for a "pedagogical and ethical commitment" (Moll, 2014, p. 142) to contextualize the "dark funds of knowledge" (Zipin, 2009, as cited by Moll, 2014) these subaltern groups have accumulated.

\section{Freire's Critical Pedagogy}

The above descriptions and narratives of teacher practices, curriculum content, and classroom pedagogy of volunteer teachers in migrant worker classrooms contextualized within discourses of racial aggression, gender inequality, and class oppression is reminiscent of the work of Paulo Freire. His seminal work, Pedagogy of the Oppressed (1970) is significant to the education of oppressed peoples. Freire's early work is based on his teaching experiences in his native Brazil where he founded a national literacy campaign and taught literacy 
skills to peasant laborers and slum dwellers. What differentiated Freire from other educators of his day was the incorporation of a socialist perspective he brought into the understanding of teaching and learning. Pedagogy of the Oppressed is not just an analysis of the traditional, authoritarian system of education, but a political critique that links the passivity of the masses to a system of education that is representative of neoliberal policies. As a means of resistance, Freire advocated for a revolutionary pedagogy that endorsed a critical view of the world. We see examples of this in Abe's classroom: he used the story of Elizabeth Eckford to teach his students to critique racism in U.S. society by reading the world; in so doing, Abe sought to build a critical consciousness within the minds of his students. Other teachers demonstrated the importance of building trust and relationships with their students - Sofia and Ashraf view the reciprocity of language teaching as a way of creating equality and reciprocity with their students.

\section{The Classroom as "Counterspace"}

In this study, the activist community functioned as the niche opening for the migrant community because of the humanitarian norms Tamkin represented, thereby creating powerful "counterspaces" (Yosso, 2006), which are "academic and social spaces that foster [student] learning" (Muñoz \& Maldonado 2012, p. 295) and served as a way "to nurture a supportive environment where their experiences were validated and viewed as important knowledge" (Yosso, 2006 ). The counterspaces within the Migrant Center, Tamkin, and MWEG are similar, and I would add that the space became appropriated to exemplify not just an educational space but a counter-cultural space as well.

\section{Conclusion: Implications of a Subaltern Pedagogy and Practice in U.S. Context}

Transnational students who have crossed borders due to poverty, natural disasters, war, and conflict are in need of educational services that better "fit" and contextualize their lived experiences. This study's contribution to the theorizing of practices of subaltern groups in non-formal educational settings in a global context heeds the call for a paradigm shift in development studies and practice by utilizing an anthropological lens and positing a subaltern praxis within the NGO educational sector (or other places of teaching and learning). An immediate example in the U.S. context is the influx of children from Latin American countries fleeing extreme violence in their home countries. It is important that educators are trained in subaltern pedagogy and practice in their Foundations of Education and Diversity in Education courses. Teaching \& Teacher Education programs in our U.S. higher education institutions should include courses that focus specifically on the education of subaltern groups. Such a course would include three main components. First, it would include an area studies component to provide context of subaltern groups' lived experiences in their home countries; second, a thorough grounding in critical pedagogy, critical race theory, critical spatial analysis, and postcolonial studies would be provided. Third, pre-service and in-service teachers would learn in methods courses how to create place-based and culturally relevant curriculum, how to contextualize dark knowledges and create niche openings, how to enact scaffolding among student groups, between students and teachers, and 
between communities and their schools; and, how to create counterspaces to build a powerful critical and social consciousness within not only our subaltern, transnational students, but all students.

\section{References}

Appadurai, A. (2000). Grassroots globalization and the research imagination. Public Culture, 12(1), 1-19.

Bhavnani, K., Foran, J., Kurian, P., \& Munshi, D. (2009). On the edges of development: Cultural interventions. Routledge.

Charmaz, K. (2006). Constructing grounded theory: A practical guide through qualitative analysis. SAGE Publishers.

Desai, V. \& Potter, R. (2014). The companion to development studies (3rd ed.). Routledge.

Duncan-Andrade, J.M.R. and Morrell, E. (2008). The art of critical pedagogy: Possibilities for moving from theory to practice. Peter Lang Publishing, Inc.

Escobar, A. (2000). Beyond the search for a paradigm? Post-development and beyond. Development, 43(4), 11-14. https://doi.org/10.1057/ palgrave.development.1110188

Escobar, A. (2011). Encountering development: The making and unmaking of the Third World. Princeton University Press.

Freire, P. (1970). Pedagogy of the oppressed. Herder and Herder.

Freire, P. (1985). Reading the world and reading the word: An interview with Paulo Freire. Language Arts. 62(1), 15-21.

Freire, P. (2005). Teachers as cultural workers: letters to those who dare teach. Westview Press.

Heath, S. B. \& Street B. V. (2008). On ethnography: Approaches to language and literacy research. Teachers College Press.

Kanpol, B. (1997). Issues and trends in critical pedagogy. Hampton Press.

Kothari, U. (2019). A radical history of development studies: individuals, institutions and ideologies. Zed Books.

McMichael, P. \& Weber, H. (2016). A Development and Social Change: A Global Perspective. SAGE Publications.

Migrant Workers Task Force. (n.d.). What we do. https://mwtaskforce.wordpress. com/our-initiatives/

Moll, L. C. (1990). Vygotsky and education: Instructional implications and applications of sociohistorical psychology. Cambridge University Press.

Moll, L. C. (2014). L.S. Vygotsky and education. Routledge. 
Muñoz, S. M., \& Maldonado, M. M. (2012). Counterstories of college persistence by undocumented Mexicana students: Navigating race, class, gender, and legal status. International Journal of Qualitative Studies in Education, 25(3), 293-315. https://doi.org/10.1080/09518398.2010.529850

Nicholls, W. J. (2014). From political opportunities to niche-openings: the dilemmas of mobilizing for immigrant rights in inhospitable environments. Theory and Society, 43(1), 23-49. https://doi.org/10.1007/s11186-013-9208-x

Rist, G. (2019). The History of development: From Western origins to global faith. Zed Books.

Sawyer, R. K. (2008). Optimising learning implications of learning sciences research. Innovating to learn, learning to innovate, 45, 35-98. https://doi.org/10.1787/9789264047983-4-en

Schuurman, F. J. (2009). Critical development theory: Moving out of the twilight zone. Third World Quarterly, 30(5), 831-848. https://doi.org/10.1080/01436590902959024

Seidman, I. (2006). Interviewing as qualitative research: A guide for researchers in education and the social sciences. Teachers College Press.

Sumner, A. \& Tribe, M. (2008). International development studies: Theories and methods in research and practice. SAGE Publications.

Teddlie, C. \& Tashakkori, A. (2009). Foundations of mixed methods research: Integrating quantitative and qualitative approaches in the social and behavioral sciences. SAGE Publications.

Tucker, V. (1999). The myth of development: A critique of Eurocentric discourse. In R. Munck \& D. O'Hearn (Eds.), Critical development theory: Contributions to a new paradigm (pp. 1-26). Zed Books.

Vygotsky, L. S. (1978). Mind in society: The development of higher psychological processes. Harvard University Press.

Yosso, T. J. (2006). Critical race counterstories along the Chicana/Chicano educational pipeline. Routledge.

Zipin, L. (2009). Dark funds of knowledge, deep funds of pedagogy: Exploring boundaries between lifeworlds and schools. Discourse: Studies in the cultural politics of education, 30(3), 317-331. https://doi.org/10.1080/01596300903037044

\section{Author Contact}

Shireen Keyl, shireen.keyl@usu.edu

School of Teacher Education and Leadership, 2805 Old Main Hill

Logan, UT 84322 